DOI : $10.14746 / \mathrm{pp} .2015 .20 .1 .6$

\title{
Agnieszka WALECKA-RYNDUCH
}

Kraków

\section{„Alternative für Deutschland” \\ - niemiecka eurosceptyczna partia pozaparlamentarna. Próba analizy wizerunku w przestrzeni internetu}

\begin{abstract}
Streszczenie: Alternatywa dla Niemiec jest nową partią na niemieckiej scenie politycznej. Mimo krótkiej obecności politycznej i medialnej (partia została utworzona w lutym 2013 roku), udało jej się mocno zaznaczyć swoją obecność w przestrzeni społeczno-politycznej. AfD występuje bowiem przeciwko establishmentowi. Co ciekawe, nazywana jest "partią profesorską", ponieważ jej członkowie i zwolennicy wywodzą się głównie ze środowisk tzw. intelektualnych: naukowych, politycznych, to cenieni eksperci $\mathrm{z}$ wielu dziedzin. AfD spowodowała spore zamieszanie w ostatnich niemieckich wyborach parlamentarnych (2013 r.). Z jednej strony poparło ją 4,7\% wyborców, zatem otarła się o próg wyborczy, z drugiej strony niechęć do niej solidarnie wykazali działacze większości opcji politycznych. Celem artykułu jest odpowiedź na pytanie: Co miało wobec tego decydujące znaczenie przy budowaniu tak stosunkowo wysokiego wyniku wyborczego (o mały włos dającego mandat wyborczy)? Czy był to potencjał społeczny, programowy czy wizerunek medialny zbudowany w sieci? Który z tych elementów dał AfD 7\% poparcie w wyborach do Parlamentu Europejskiego w 2014 r.?
\end{abstract}

Slowa klucze: public relations, potencjał medialny, identyfikacja wizerunkowa, partie pozaparlamentarne, Alternatywa dla Niemiec

B adanie strategii komunikacyjnych, marketingowych i PR-owych partii politycznych w zakresie budowania wizerunku ${ }^{1}$ jest tematem ciekawym i ważnym. Takiej analizy warto dokonać na dwóch płaszczyznach naukowych. Z jednej strony należy pokazać procesy, które rządzą politykami i polityką, z drugiej strony przyjrzeć się poznawczo ważnemu aspektowi, jakim jest relacja pomiędzy wykreowanym za pomocą wizerunku potencjałem medialnym a wynikiem politycznym, czyli zainteresowaniem obywateli przekładającym się ostatecznie na głosy wyborcze. Należy wspomnieć, że aktorzy polityczni, media masowe i obywatele tworzą tzw. „złoty trójkąt”, w którym wszyscy mają porównywalne narzędzia oddziaływania, jednak zachodzące między nimi procesy komunikacyjne nie mają charakteru symetrycznego (Dobek-Ostrowska, 2007, s. 163).

Nie bez znaczenia dla tych procesów jest pogłębiające się zjawisko politycznej mediatyzacji, pod pojęciem której rozumie się ,zespół procesów wynikających ze zmian zarówno w samych mediach, jak i zmian społecznych oraz kulturowych" (Michalczyk,

${ }^{1}$ Pod pojęciem wizerunku rozumiem, zgodnie z definicją Krystyny Wojcik, „wyobrażenie, jakie jedna lub wiele publiczności ma o osobie, przedsiębiorstwie lub instytucji; nie jest to obraz rzeczywisty, dokładnie i szczegółowo nakreślony, ale raczej mozaika wielu szczegółów" (cyt za: Wojcik, 2005, s. 41). 
2009, s. 23). W literaturze przedmiotu wskazuje się na trzy impulsy, które powodowały tym zjawiskiem:

1) Event Impulse - wydarzenia polityczne są specjalnie organizowane dla mediów i inscenizowane tak jak w teatrze;

2) Commercial Impulse - podporządkowanie świata mediów i komunikacji politycznej regułom rynkowym;

3) Professional Impulse - profesjonalizacja komunikacji politycznej, działają wyspecjalizowane agentury i organizacje doradcze i szkoleniowe ${ }^{2}$.

Mediatyzacja polityki spowodowała jednocześnie jej personalizację, głównie przez - jak wskazuje Dorota Piontek - , polityków, którzy ustawicznie prowadzą kampanię wizerunkową" (Piontek, 2009, s. 171). Samo pojęcie wizerunku również przeszło ogromną ewolucję pod względem wartości i ważności w politycznej rywalizacji. Budowanie/tworzenie/kreowanie odpowiedniego i pożądanego przez otoczenie wizerunku, stało się również kluczowym elementem dla sposobu prowadzenia kampanii wyborczej. Istnieją bowiem trzy - jak udowadnia Kathleen M. McGraw - psychologiczne procesy, które mają decydujące znaczenie dla zrozumienia mechanizmów rządzących tworzeniem i sterowaniem wizerunkiem (McGraw, 2008, s. 360-361). To poznanie, afekt i motywacja. Poznanie oznacza całość procesów umysłowych zaangażowanych w rozumienie świata politycznego, np. jak ludzie spostrzegają innych ludzi, grupy, kierunki polityki i wydarzenia (McGraw, 2008, s. 360-361). Afekt odnosi się do preferencji elektoratu, jego ocen, nastrojów, szeroko rozumianych emocji (McGraw, 2008, s. 360-361). Motywacja oznacza szereg psychologicznych mechanizmów sterujących myśleniem i zachowaniem. Motywy to, świadome lub też nie, racje, które stoją za konkretnymi wyborami jednostkowymi (McGraw, 2008, s. 360-361).

Jednym z elementów analizy będzie wskazanie na miejsce i rolę partii pozaparlamentarnych, które kształtują scenę pozaparlamentarną w Niemczech. Partie pozaparlamentarne, podobnie jak partie mainstreamowe spełniaja, zgodnie z kategoryzacją zaproponowaną przez Ulricha von Alemana, sześć z siedmiu podstawowych funkcji: partycypacji, transmisji, selekcji, integracji, socjalizacji, samoregulacji ${ }^{3}$. Celowo pominęłam funkcję legitymizacji, ponieważ $\mathrm{w}$ większości przypadków partie pozaparlamentarne dążą do zmiany istniejącego porządku, a nie do jego legitymizacji.

Stosunkowo przewidywalna niemiecka scena parlamentarna (chociaż, jak pokazały wrześniowe wybory parlamentarne 2013 roku i wybory europejskie 2014 roku, i ona zdolna jest do zaskoczeń i zwrotów akcji) może pochwalić się sporą ilością pozaparla-

\footnotetext{
${ }^{2}$ Typologia przedstawiona za: Małkiewicz, Kessler, s. 5.

${ }^{3}$ Funkcja partycypacji umożliwia obywatelom m.in. przenoszenie interesów do programów, celów i działań partyjnych. Członkowie partii mają ponadto przywilej brania udziału w nominacjach kandydatów do różnych wyborów; funkcja transmisji polega na agregacji społecznych interesów do działań politycznych; funkcja selekcji oznacza wybór alternatyw z ogólnospołecznego działania oraz rekrutację przedstawicieli; funkcja integracji polega na zbliżeniu grup społecznych do struktur i procesów politycznych; funkcja socjalizacji umożliwia realizację różnych form aktywności podejmowanych w ramach partii politycznych i związków interesu; funkcja samoregulacji przejawia się między innymi w tworzeniu organizacji stowarzyszonych, fundacji partyjnych, przedsięwzięć, gremiów doradczych (cyt. za: U. von Aleman, Das Parteisystem der Bundesrepublik Deutschland, Bonn 2003, s. 212-217, za: K. A. Wojtaszczyk, Partie polityczne w Niemczech, Warszawa 2004, s. 15-16).
} 
mentarnych partii, które mniej lub bardziej systematycznie starają się brać udział w rywalizacji politycznej. W moim przekonaniu warto poddać analizie elementy medialnego wizerunku, którym dysponują te jednostki. Są one bowiem bardziej eksponowane w przestrzeni publicznej, niż same założenia polityczne. Ta chęć zaistnienia w przestrzeni politycznej (przede wszystkim w internetowej) jest interesującym zjawiskiem. Tu trzeba zaznaczyć, że partie pozaparlamentarne, w tym także niemieckie, budują swój wizerunek przede wszystkim w przestrzeni internetu i tylko ten obszar zamieszczanych treści zostanie poddany analizie. Każda z tych partii wypracowała już jakiś jeden spójny element wizerunkowy, dzięki któremu jest rozpoznawalna, każda integruje swoich zwolenników wykorzystując media społecznościowe. Warto zatem spojrzeć na językowe i pozajęzykowe elementy kodujące wizerunek partii. Mam tu na myśli warstwę programowo-kadrową i medialno-relacyjną, czyli stosowane nazwy, skróty, elementy graficzne (logotypy) i in. oraz nawiązanie lub jego całkowity brak do historycznej myśli politycznej, zaangażowane zaplecze kadrowe (czynnych polityków, polityków, którzy kiedyś byli aktywną siłą, osób znanych: celebrytów politycznych lub artystycznych; lub osób kompletnie nieznanych szerszej publiczności).

Ważnym składnikiem wizerunku budowanego przez partie pozaparlamentarne jest krystalizowanie postaw niezadowolonych obywateli wobec zastanego porządku politycznego. Zazwyczaj dzieje się tak, że obywatele tworzą oddolną, pozasystemową strukturę (ruch społeczny) i starają się wywierać nacisk na władzę w celu przeprowadzenia konkretnej zmiany. Takie działania, jak napisał Tadeusz Paleczny, "są próbą poszukiwania rozwiązań w sytuacji niepewności, kryzysu dotychczasowych instytucji i organizacji publicznych" (Paleczny, 2011, s. 9). Powstawanie ruchów społecznych można łączyć - jak to opisują Donatella della Porta i Mario Diani - z pojawieniem się sprzecznych systemów wartości i skonfliktowanych ze sobą grup. Gdy tradycyjne normy zawodzą, jednostki są zmuszone do kwestionowania obowiązującego porządku (della Porta, Diani, 2009, s. 14-15).

Coraz częściej ci, którzy chcą zanegować istniejącą władzę państwową, system demokratyczny, łączą się w strukturę - pozaparlamentarną partię i zaczynają oddziaływać na politykę państwową ${ }^{4}$. W takiej strukturze, uczestnicy, czy to za pośrednictwem sieci, czy używając realnych narzędzi protestują, ale w odróżnieniu od ruchów nieformalnych robią to $\mathrm{w}$ ramach państwowej instytucji, podtrzymującej system parlamentarny.

Przykładem takiej kontestacji porządku europejskiego, determinowanego w znacznym stopniu przez unię walutową, jest nowopowstała Alternatywa dla Niemiec. Została ona założona 6 lutego 2013 roku, pierwszy zjazd konstytuujący partię odbył się w kwietniu. Występuje przeciwko establishmentowi i pomysłom gospodarczym prezentowanym przez partie politycznego centrum. Partia złożona z intelektualistów, naukowców i byłych polityków spowodowała spore zamieszanie w tegorocznych wyborach parlamentarnych. $\mathrm{Z}$ jednej strony w wyborach do Bundestagu poparło ją 4,7\% wyborców, zatem otarła się o próg wyborczy, z drugiej strony niechęć do niej solidarnie wykazują działacze większości opcji politycznych.

${ }^{4} \mathrm{~W}$ Niemczech zarejestrowano przed wyborami do Bundestagu 24 partie pozaparlamentarne. W większości publikacji podkreśla się, że mają one marginalne znaczenie. Opinie te nie uwzględniają jednak życia partii w przestrzeni sieci. Nie liczą zwolenników zalogowanych na portalach społecznościowych typu Facebook, Twitter i inne. 
Celem artykułu jest analiza promocji wizerunku partii w przestrzeni internetu - praktycznego zastosowania narzędzi politycznych public relations, w tym także analiza spotów wyborczych, haseł, sloganów wyborczych i krótka analiza programowa - a to w celu wykazania, w jakim stopniu działania wizerunkowe wpływają na poziom rozpoznawalności i w efekcie na wynik wyborczy partii politycznej, zwłaszcza w przypadku partii, która nie posiada szerokiej bazy organizacyjnej (typowej dla partii głównego nurtu).

\section{Strategia wizerunkowa i polityczne PR}

Budowanie wizerunku partii politycznej, jej rozpoznawalności, jest istotnym elementem kształtowania politycznych relacji z elektoratem. Pierwszym krokiem w tworzeniu wizerunku partii jest poznanie potrzeb, oczekiwań, jak i cech osobowości grupy społecznej, do której adresuje ona swój program polityczny i od której oczekuje poparcia wyborczego. Drugim aspektem jest prawidłowe rozpoznanie płaszczyzn kreowania wizerunku politycznego. Zgodnie z typologią zastosowaną przez Izabelę Podobas możemy wyróżnić cztery takie płaszczyzny: merytoryczną, emocjonalną, personalną i komercyjną (Podobas, 2011, s. 86-87).

Te kategorie sąjednak za szerokie, jeżeli analizie mają zostać poddane partie pozaparlamentarne, szczególnie te o charakterze mocno marginalnym. Na potrzeby takiego badania, jak mi się wydaje, można przyjąć jako miarodajne dwie płaszczyzny:

- programowo-kadrową;

- medialno-relacyjną 5 .

Pierwsza określać będzie zasady programowe, które definiują partię na scenie politycznej, w tym czas funkcjonowania i zaplecze historyczne, nawiązywanie do konkretnej idei bądź doktryny politycznej, lub też programu politycznego innej (historycznie wcześniejszej) organizacji. Drugi człon, czyli zaplecze kadrowe, to w moim ujęciu osoby liderów politycznych, ich charyzma, rozpoznawalność na rynku politycznym oraz wcześniejsze deklaracje przynależnościowe do innych partii politycznych, tak mainstreamowych, jak i pozaparlamentarnych.

Druga płaszczyzna natomiast obejmuje przede wszystkim wypracowany przez partię wizerunek medialny, w tym system identyfikacji wizualnej partii, czyli występowanie w semisferze - używanie znaków, symboli, kolorów, nawiązywanie do mitów i kodów kulturowych. W tym aspekcie istotny będzie również sposób budowania przez partie kampanii medialnej za pomocą tradycyjnych i nowych metod tworzenia relacji z potencjalnymi sympatykami, zwolennikami, może przyszłym elektoratem. Do tradycyjnych metod zaliczam te, które umożliwiają stworzenie bezpośredniej relacji z członkami i sympatykami partii: wiece, mityngi, debaty i inne spotkania służące autoprezentacji i prezentacji programu politycznego. Nowe metody to te, które oparte są na funkcjonowaniu w przestrzeni internetu, czyli wykorzystywanie przez partię lub polityka/polityków me-

${ }^{5}$ Celowo posługuję się tu terminem ,relacyjny”, nawiązując tym samym do koncepcji prof. Ewy M. Marciniak, która łącząc marketing relacyjny z marketingiem politycznym zwraca uwagę na renesans komunikacji bezpośredniej w polityce. Marketing relacji opiera się na budowaniu poczucia więzi i wspólnoty z tymi, którzy są skłonni identyfikować się z określoną ideą (więcej na ten temat patrz: Marciniak, 2012). 
diów internetowych, utrzymywanie kontaktów ze zwolennikami za pomocą komunikatorów (obszar social media), blogów i innych kanałów komunikacji oraz treści zamieszczanych na stronach www.

Obydwa te elementy (płaszczyzna pierwsza i druga) składać się będą na prestiż i reputację partii, które są obecnie w znacznie większym stopniu pochodną właśnie działań medialno-relacyjnych niż ideowego promieniowania programu czy poglądów poszczególnych liderów.

Gdy przyłożyć ten schemat (w aspekcie analizy programowej) do strategii programowej AfD, uwagę zwraca przede wszystkim gospodarcza część programu; dla potrzeb artykułu (i dla przybliżenia zrębów programu AfD czytelnikowi polskiemu) przytaczam bardziej szczegółowo trzy punkty programowe: polityka walutowa, polityka europejska, państwo prawa i demokracji ${ }^{6}$.

W zakresie polityki walutowej Alternatywa opracowała siedmiopunktową strategię presupozycyjną:

— „domagamy się uporządkowanego rozwiązania sfery euro. Niemcy nie potrzebują euro, innym krajom euro szkodzi;

— domagamy się przywrócenia walut narodowych lub utworzenia mniejszych unii walutowych. Ponowne wprowadzenie Deutsche Mark nie może być tematem tabu;

- domagamy się zmiany Traktatów Europejskich, aby umożliwić każdemu państwu odejście od euro - każdy naród musi mieć możliwość demokratycznego decydowania o swojej walucie;

- domagamy się, aby Niemcy wymusiły prawo do wyjścia ze strefy euro poprzez zablokowanie za pomocą weta dalszych kredytów pomocowych z Europejskiego Mechanizmu Stabilizacyjnego;

— domagamy się, aby koszty tzw. polityki walutowej nie były ponoszone przez podatników. Banki, fundusze hedgingowe i prywatni inwestorzy są beneficjentami tej polityki i muszą za nią ponosić odpowiedzialność;

— domagamy się, aby beznadziejnie zadłużone kraje, takie jak Grecja, mogły pozbyć się długów poprzez ich umorzenie. W kryzysie zadłużone banki same muszą pokryć swoje straty lub odzyskać stabilność kosztem swoich prywatnych wierzycieli;

— domagamy się natychmiastowego zakazu nabywania »śmieciowych« obligacji przez Europejski Bank Centralny. Inflacja nie może »pożerać« oszczędności obywateli” (https://www.alternativefuer.de/partei/wahlprogramm/).

W obszarze polityki europejskiej AfD prezentuje następujące rozwiązania:

— ,jesteśmy za Europą suwerennych państw, ze wspólnym rynkiem wewnętrznym. Chcemy żyć w przyjaźni i dobrym sąsiedztwie;

— jesteśmy za nieograniczonym prawem parlamentów krajowych do kształtowania budżetów. Zdecydowanie odrzucamy Unię polegającą na transferze środków, czy wręcz scentralizowane państwo europejskie;

— zadbamy o to, aby kompetencje kształtowania prawa powróciły do parlamentów państw członkowskich;

\footnotetext{
${ }^{6}$ Nie poddaję zacytowanych tutaj elementów programu politycznego głębszej analizie, albowiem tematem tego artykułu jest budowa wizerunku partii w przestrzeni internetu.
} 
— będziemy działać na rzecz reformy Unii Europejskiej, aby zredukować biurokrację Brukseli; będziemy wspierać przejrzystość i bliski kontakt z obywatelami;

— ponieważ Parlament Europejski zawiódł w kontroli Brukseli, zdecydowanie popieramy stanowisko Davida Camerona, aby usprawnić Unię Europejską poprzez zwiększenie konkurencyjności i odpowiedzialności za siebie samego" (https://www.alternativefuer.de/partei/wahlprogramm/).

W punkcie „Państwo prawa i demokracji” czytamy:

— „żądamy, aby zasada państwa prawa przestrzegana była bez żadnych kompromisów. Organy państwa nie mogą stawiać się w określonych sytuacjach ponad prawem lub traktatami. Mają one respektować prawo zgodnie z jego literą i duchem;

— działanie każdego niemieckiego rządu ograniczone jest prawem międzynarodowym, konstytucją i traktatami europejskimi. To prawo jest dla naszego społeczeństwa fundamentalne i winno być ściśle przestrzegane;

— jesteśmy za tym, aby także niekonwencjonalne poglądy poddawane były otwartej dyskusji w dyskursie politycznym, dopóki tylko poglądy takie nie naruszają wartości zawartych w konstytucji” (https://www.alternativefuer.de/partei/wahlprogramm/).

Elementem strategii programowej jest postulat wzmocnienia demokracji. Partia krytykuje istniejące partie systemowe, twierdząc, że stały się one zbyt silnymi organizmami na scenie politycznej. Partie powinny współdziałać w ramach systemu politycznego, a nie zawłaszczać go. „To naród powinien określać wolę partii, nie odwrotnie”. Żądają powrotu do zasad demokracji bezpośredniej opartej na systemie referendalnym i inicjatywach ludowych na wzór szwajcarski (Plickert, „Frankfurter Allgemeine Zeitung”). To wzmocniłoby demokrację i demokratyczne prawa obywateli (https://www.alternativefuer.de/partei/wahlprogramm).

Pojawia się również żądanie, aby deputowani poświęcali całą swoją aktywność na pracę w parlamencie, mandat nie może ,cierpieć” ze względu na inne, płatne, zajęcia dodatkowe (https://www.alternativefuer.de/partei/wahlprogramm).

Drugi człon, czyli zaplecze kadrowe, czyli ilość i jakość kadry kierowniczej, rozpoznawalność, ilość zwolenników, oraz aktywność polityków partii pozaparlamentarnych w bieżącej polityce państwowej odgrywa w przypadku Alternatywy kluczową rolę, szczególnie ze względu na ich wyjątkowe role społeczne. Wszyscy zasiadający we władzach partii to osoby zaangażowane w sprawy niemieckiej polityki i nauki. Cenieni intelektualiści, profesorowie, dziennikarze. Piastujący w swoich karierach zawodowych istotne stanowiska państwowe, zaangażowani w sprawy charytatywne.

$\mathrm{Na}$ czele partii stoi kolegialnie trzech prezesów/prezydentów:

- Bernd Lucke, profesor ekonomii na Uniwersytecie w Hamburgu; założyciel i prezes „Plenum Ekonomistów” skupiającego ponad 300 profesorów ekonomii, które w lutym 2011 roku opowiedziało się przeciwko mechanizmom ratunkowym UE; przewodniczący stowarzyszenia „Wola Obywatelska”;

- Frauke Petry, doktor chemii, przedsiębiorca;

- Konrad Adam, doktor nauk humanistycznych, absolwent filologii klasycznej, historii i filozofii, dziennikarz ${ }^{7}$.

${ }^{7}$ W strukturze partii istnieje również Rada Naukowa: przewodniczy jej Joachim Starbatty, emerytowany profesor ekonomii na Uniwersytecie w Tybindze. W latach 1998 i 2011 zgłaszał skargę konstytucyjną przed Federalnym Trybunałem Konstytucyjnym przeciwko wprowadzeniu euro i przeciwko 
Wiceprezydentami są:

- Alexander Gauland, były sekretarz stanu w rządzie Hesji za czasów CDU (1987-1991), przedsiębiorca, wydawca i szef gazety „Märkische Allgemeine Zeitung”;

- Patricia Casale, nauczycielka, księgowa, zaangażowana w sprawy charytatywne, w tym w pomoc imigrantkom;

- Roland Klaus, dziennikarz ekonomiczny komentujący wydarzenia z frankfurckiej giełdy.

Warto zwróć również uwagę na szerokie grono zdeklarowanych sympatyków AfD. Nie są oni członkami partii, ale wyraźnie z nią sympatyzują, stanowią też (patrząc z PR-owego punktu widzenia) rodzaj liderów opinii publicznej ${ }^{8}$, którzy dzięki swojej wysokiej pozycji w społeczeństwie stanowiąźródło pozyskiwania sympatii dla partii ${ }^{9}$.

Druga płaszczyzna, za pomocą której można zrozumieć strategię przyjętą przez AfD, to płaszczyzna komercyjno-relacyjna, zakładająca m.in. posługiwanie się mediami społecznościowymi, utrzymywanie kontaktów ze zwolennikami za pomocą komunikatorów, blogów i innych kanałów komunikacji oraz organizowanie wieców, mityngów i innych spotkań służących pozyskaniu zwolenników oraz prezentowaniu własnej oferty programowej. W tym kontekście AfD posługuje się i tradycyjnymi, i nowoczesnymi metodami kontaktów z wyborcami. Do tradycyjnych metod zaliczam spotkania wyborcze, konferencje prasowe, konferencje oparte na odpowiadaniu na pytania internautów, debaty polityczne. AfD konsekwentnie aktywizuje wszystkie oddziały landowe (terenowe). Poszczególni lokalni liderzy na plakatach i ulotkach wyborczych ściskają dłoń Berndowi Lucke - to strategia marketingowa świecenia światłem odbitym, polegająca na tzw. transferze image'u, czyli wpływie „ogólnego wrażenia na specjalne wrażenie”. Jak wska-

prowadzeniu Europejskiego Mechanizmu Stabilizacyjnego; Jörn Kruse, profesor ekonomii na Uniwersytecie Helmuta Schmidta w Hamburgu; Helga Luckenbach, emerytowana profesor ekonomii na Uniwersytecie Justusa Liebiga w Gießen; Dirk Meyer, profesor ekonomii na Uniwersytecie Helmuta Schmidta w Hamburgu; Roland Vaubel, profesor ekonomii na Uniwersytecie w Mannheim.

${ }^{8}$ Liderów opinii (osoby cieszące się szacunkiem) można, zgodnie z teorią Sama Blacka, podzielić na dwie kategorie: liderów formalnych, uznanych ze względu na swoje znaczenie lub pozycję (parlamentarzyści, nauczyciele, osoby duchowne) i liderów nieformalnych, którzy ze względu na swoją charyzmę, osobowość lub pochodzenie wywierają silny wpływ na odbiorców (więcej na ten temat patrz: Black, 2005, s. 54 i dalej).

${ }^{9}$ Wydaje mi się, że warto przytoczyć tu następujące osobistości świata biznesu, nauki i mediów: prof. dr Hans-Günter Appel, przewodniczący Rady Narodowego Ruchu Przeciwko Ustawie o Odnawialnych Źródłach Energii; prof. dr. Ursula Braun-Moser, europarlametarzystka (CDU) w latach 1984-1994; Peter Christ, były szef redakcji ekonomicznej „Die Zeit” i redaktor naczelny „Stuttgarter Zeitung”, „Manager Magazin”, „Sächsische Zeitung” i in., Luzern; Wolfgang von Eichborn, sędzia, były rzecznik frakcji SPD w Bundestagu, Ebersberg; Albrecht Glaser, asesor, były skarbnik miasta Frankfurt nad Menem, były burmistrz, Niedenstein; prof. dr Wilhelm Hankel, były prezes Heskiego Banku Krajowego, Königswinter; prof. dr ing. E.h. Hans-Olaf Henkel, prezes IBM Europa, Federalnego Zrzeszenia Niemieckich Przemysłowców (BDI) i Wspólnoty Leibniza; dr Wolfgang Hönig, były pełnomocnik generalny Commerzbank AG, Frankfurt; dr Klaus-Peter Last, informatyk, 1991-1998 skarbnik partii Bündnis90/Die Grünen w Meklemburgii-Pomorzu Przednim; Hansjörg Schrade, ecofit, wiceprzewodniczący koalicji Demokracja Bezpośrednia, Reutlingen; dr Bernhard Seitz, koalicja Demokracja Bezpośrednia, Stuttgart (pełna lista osób sympatyzujących z AfD dostępna jest na: https://www.alternativefuer.de/partei/unterstutzer/, styczeń 2014). 
zuje Krystyna Wojcik, ,przez ten psychiczny mechanizm ogólne nastawienie do jakiegoś przedmiotu wpływa na postrzeganie właściwe tego przedmiotu” (Wojcik, 2005, s. 49). W przestrzeni internetu, którą zaliczam do nowoczesnych metod politycznej komunikacji, Alternatywa posługuje się profesjonalnym przekazem medialnym i w obszarze komunikacji perswazyjnej wykorzystuje model symetrycznego komunikowania dwukierunkowego $^{10}$. W opinii Agnieszki Hess ten model najpełniej realizuje zadanie komunikacji między podmiotem a jego otoczeniem, przyjmując formę ,równouprawnionego dialogu nadawcy z odbiorca, którego rezultatem może być nie tylko skuteczne budowanie wzajemnej interakcji, a następnie jej podtrzymywanie, ale wręcz stworzenie szczególnego rodzaju więzi społecznej, której obecność jest korzystna dla obu stron" (Hess, 2013, s. 242-243). Trudno orzec, przy tak krótkiej obecności partii na rynku politycznym, ile osób zaangażowanych jest w tworzenie strategii wizerunkowej partii. Nie wiadomo, czy podejmowane przez AfD działania są wynikiem działania agencji PR, czy też pojedynczych osób - może przywódców partyjnych. Trzeba też zaznaczyć, że partie polityczne rzadko kiedy udostępniają tego typu informacje szeroko rozumianej opinii publicznej. Wyjątkami są tylko sytuacje kryzysowe lub tzw. „medialne” wpadki. Partyjna strona www zbudowana została zgodnie ze współczesnym schematem strategii komunikacyjnych. WWW jest medium, w którym nadawca w pierwszej kolejności decyduje o kształcie i treści sytuacji komunikacyjnej. Zgodnie ze schematem kategoryzacji opracowanym przez Hess, patrząc na witrynę internetową należy poddać analizie zarówno wskaźniki paradygmatu Web 1.0 (komunikacja jednokierunkowa) jak i 2.0 (komunikacja dwukierunkowa). Do paradygmatu pierwszego należą: dane kontaktowe, zdjęcia i materiały audiowizualne, elementy rozrywkowe, promowane media własne, relacje z mediami, formy angażowania obywateli. Do drugiego: portale społecznościowe i sprzężenie zwrotne, czyli możliwość komentowania, opiniowania udostępnianych treści (Hess, 2013, s. 244). Alternatywa wykorzystuje wszystkie te elementy na stronie www. Dużą uwage przywiązuje do kontaktów z mediami (media relations). Oprócz standardowych danych teleadresowych do osób odpowiedzialnych za kontakty $\mathrm{z}$ mediami ${ }^{11}$, można skorzystać także $\mathrm{z}$ otwartego centrum prasowego ${ }^{12}$, opracowanego $\mathrm{w}$ formie archiwum,

${ }^{10} \mathrm{~W}$ literaturze przedmiotu z zakresu public relations wykorzystuje się następujące modele teoretyczne ukazujące wzajemne relacje między organizacją i mediami w kontekście działań perswazyjnych. Jako pierwsi takie ujęcie zaproponowali w 1984 roku J. E. Grunig i T. Hunt, Managing Public Relations, New York. Wyróżnione przez nich modele to: publicity (organizacja skupia się głównie na współpracy z mediami, zabiegając o pozytywne publikacje); informowanie opinii publicznej (filozofią organizacji staje się głównie szczere informowanie otoczenia o działaniach firmy, celem jest pozyskanie opinii publicznej); asymetryczna komunikacja dwustronna (oparta na przekonaniu opinii publicznej do tego, aby przejmowała punkt widzenia organizacji); symetryczna komunikacja dwustronna (oparta na dialogu «komunikowaniu i słuchaniu», redukowaniu negatywnych wrażeń i wpływów na opinię publiczną, ale także dopasowywaniem się do oczekiwań otoczenia) (więcej na ten temat patrz: B. Rozwadowska, $P u$ blic Relations. Teoria i praktyka, Warszawa 2009, s. 48-51).

${ }^{11}$ Aktualnie na stronie internetowej w zakładce PR i social media figurują dwie osoby odpowiedzialne za media relations: Christian Lüth, rzecznik prasowy Alternatywy dla Niemiec (christian.lueth@alternativefuer.de) oraz Tobias Zeiler, specjalista ds. PR i nowych mediów (tobias.zeiler@alternativefuer.de).

${ }^{12}$ Centra prasowe są istotnym elementem komunikacji pomiędzy partią a mediami i elektoratem. Zgodnie z teorią internet public relations powinny one zawierać następujące elementy: kontakt do rzecz- 
w którym umieszczone są artykuły odnoszące się lub opisujące działalność AfD, które ukazały się od kwietnia 2013 r. (momentu powstania partii), w opiniotwórczej prasie niemieckiej. Istnieje również możliwość zamówienia informacji o bieżących wydarzeniach w AfD w formie newslettera.

Ciekawym zabiegiem wizerunkowym w przestrzeni internetu jest stworzony przez AfD portal „AfD Antwortet”; jak wyjaśniają zainteresowani: „AFD odpowiada” jest portalem stworzonym do komentowania przez partię doniesień medialnych, szczególnie tych, które zawierają nieprawidłowe informacje. Został on powołany, „ponieważ niektóre media nie były skłonne do publikowania wyjaśnień naszego Rzecznika" (https://www.alternativefuer.de/grosse-aufmerksamkeit-fuer-afd-antwortet). „W tym miejscu - jak wyraził się Lucke w komunikacie skierowanym do partyjnych kolegów (bazy) - będziemy w przyszłości odnosić się do tendencyjnych artykułów prasowych i korygować nieprawdziwe informacje. Będziemy się starać robić to tak szybko jak tylko się da, ale nie oczekujcie, że będziemy stali na baczność i reagowali na każdy negatywny artykul" (https://www.alternativefuer.de/grosse-aufmerksamkeit-fuer-afd-antwortet).

Stworzenie takiego portalu pozwala stwierdzić, że strona www jest dla AfD równie istotną platforma porozumienia z potencjalnymi wyborcami, jak formy tradycyjne (np. mityngi wyborcze). Co więcej, wpisuje się również w założenia nakreślone przez Frasera Seitla, który w publikacji Public relations w praktyce wskazał, że wzrasta liczba dziennikarzy, którzy w swojej codziennej pracy korzystają z sieci jako podstawowego źródła informacji, a strony www firm czy partii są drugim pod względem ważności źródłem informacji dla odbiorców (Seitel, 2003, s. 338). Z perspektywy partii pozaparlamentarnych strony www są prawdopodobnie źródłem pierwszym i jednym, dlatego każda z partii stara się konsekwentnie budować swój medialny wizerunek głównie za pomocą witryn www.

Aktywność Alternatywy widoczna jest również w mediach społecznościowych Facebook, Tweeter, Youtube. Profil na Facebooku do końca stycznia 2014 r. polubiło (,zalajkowało") 90726 osób, w maju, tuż przed wyborami do europarlamentu było ich już 109 tys. Dla porównania w tym samym czasie CDU miała 78 tys. „lajków”, a SPD 71 tys. Szacuje się, że partia ma ok. 17 tys. sympatyków (http://www.zeit.de/2013/51/afd-alternative-fuer-deutschland-rechts), którzy komentują bieżące wydarzenia, a co jest godne podkreślenia, to fakt, że komunikaty, które wymieniają, mają charakter merytorycznej debaty. To robi i powinno robić wrażenie. Dla porównania: liberałowie (FDP) i Sojusz 90/Zieloni mają łącznie 60 tys. członków (http://www.dw.de/niemiecka-tea-party-cichy-zwyci\%C4\%99zca-wybor\%C3\%B3w-do-bundestagu/a-17104630).

Analiza tej płaszczyzny prowadzi także do wniosku, że istotnym elementem politycznych public relations $\mathrm{w}$ ramach strategii wizerunkowych jest zawarty w komponencie medialno-relacyjnym system wizualnej identyfikacji. Każda organizacja wytwarza bo-

nika prasowego lub do osób, które kontaktują się z mediami, lub do działu public relations. Dobrym zwyczajem jest również zamieszczanie przy komunikatach danych ich autorów. Więcej na temat wykorzystania biura prasowego w teorii i praktyce internet public relations patrz: M. Kaczmarek-Śliwińska, Internet public relations. Polskie realia działań public relations w sieci, Koszalin 2010, s. 53 i dalej. Trzeba podkreślić, że pod tym względem AfD doskonale wypełnia wszelkie zalecenia z zakresu media relations. 
wiem inną kulturę komunikacyjną jako sumę z jednej strony wyznawanych wartości, a z drugiej - praktyki w zakresie nawiązywania relacji z otoczeniem. Jest to element kluczowy dla rozwoju każdej organizacji, w tym również partii politycznej, i zasadniczo wpływa na jej postrzeganie, a co za tym idzie - na odbiór zewnętrzny (Rychter, Chmielewski, Tworzydło, 2012, s. 84-85).

Jak zauważa Janina Fras, samoidentyfikacja partii politycznych dokonywana jest zarówno na potrzeby wewnętrzne (indywidualna identyfikacja), jak też przede wszystkim na potrzeby zewnętrzne, czyli po to, aby się odróżnić od innych partii, żeby zjednać potencjalnych członków i wyborców (Fras, 2010, s. 151). Ciekawym aspektem samoidentyfikacji partii politycznej na potrzeby wewnętrzne, czyli na potrzeby członków partii jest istniejący od czasu wyborów do Parlamentu Europejskiego sklep internetowy, w którym w okresie okołowyborczym w ramach akcji: „Mir geht ein Licht auf!”,13 można było kupić t-shirty oraz zestaw pięciu plakatów identyfikujących zwolenników partii.
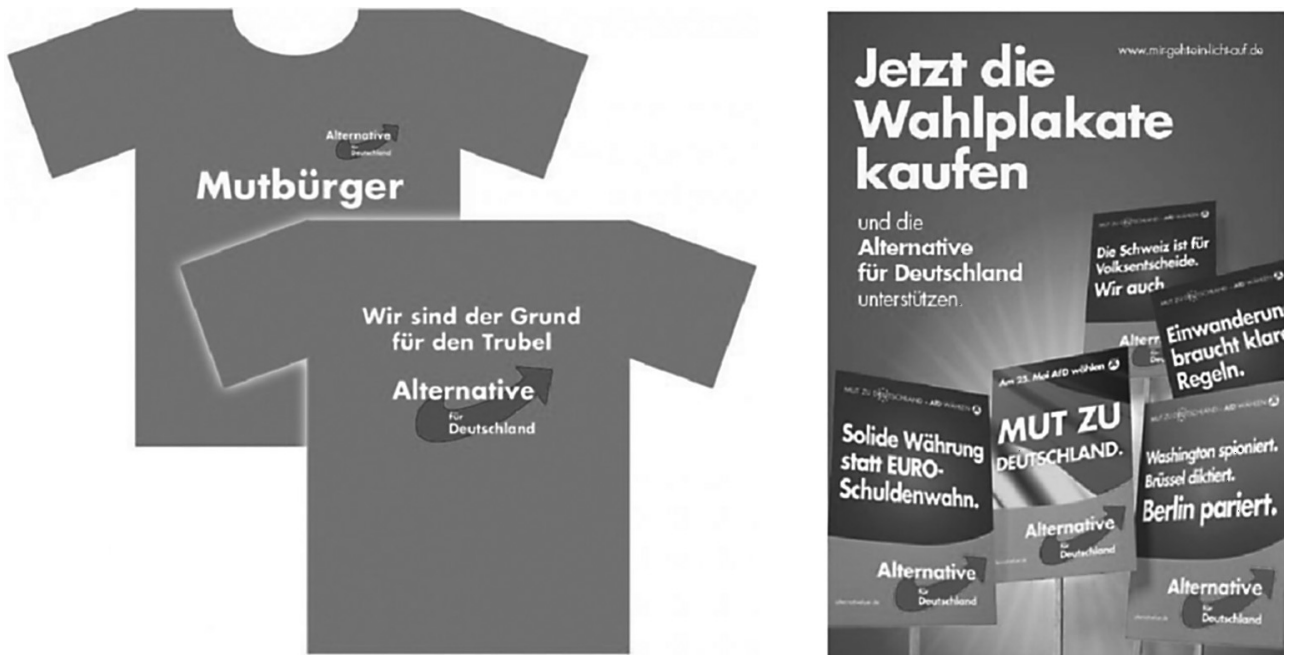

Źródło: http://www.mir-geht-ein-licht-auf.de/MutBuerger-AfD-T-Shirt ${ }^{14}$.

Analizując strategię identyfikacji wizerunkowej AfD, warto zwrócić uwagę na dwa czynniki: kody językowe i niejęzykowe. Do kodów prymarnie językowych zalicza się funkcjonującą nazwę partii (ewentualnie skrót, akronim), motto, hasło, które ją wyróżnia, funkcjonującą stronę www, gazetę, biuletyn partyjny. Alternatywa wydaje (internetowy) biuletyn partyjny w formie newslettera „AfD Kompakt”, utrwalający w dyskursie politycznym akronim i informujący o istotnych wydarzeniach w konstytuowaniu się i funkcjonowaniu partii.

${ }^{13}$ W wolnym tłumaczeniu: „I wszystko jasne!” - to akcja wskazująca na nadużycia brukselskiej biurokracji związane z zakazem stosowania tradycyjnych żarówek na rzecz jarzeniówek energooszczędnych, co miałoby być wynikiem skutecznego lobbingu na poziomie europejskim. W ramach tej prowokacyjnej akcji na stronie AfD można było także kupić tradycyjne żarówki.

${ }^{14}$ Uwagę zwraca słowna gra. Mutbürger można przetłumaczyć jako „Odważny Obywatel”, Mut - odwaga Mitbürger - współobywatel. 
Źródlo: https://www.alternativefuer.de/wp-content/uploads/2014/05/AfD_Kompakt_06_14.pdf,

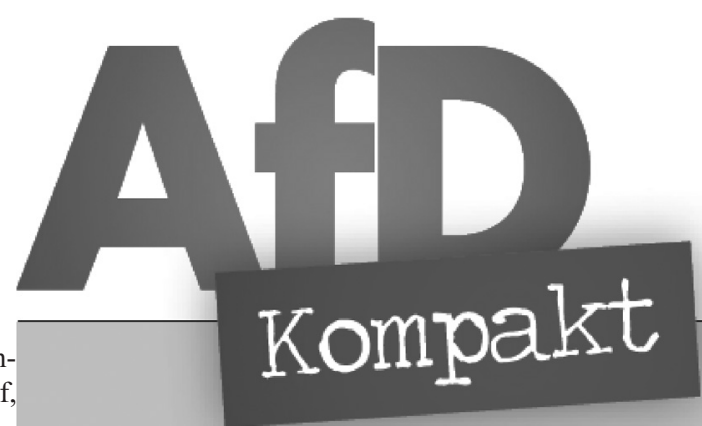
maj 2014.

W kwestii przyjętej nomenklatury związanej z nazwą: partia nie wpisuje się w tradycyjny nurt samoidentyfikacji polityczno-partyjnej, nie używa bowiem w nazwie słowa „partia”. Przyjęła strategię postulatywno-deklaratywną polegającą na tym, że nazwa partii lub jeden z jej członów może być jednocześnie sloganem wyborczym (Fras, 2010, s. 151). Występują bowiem jako Alternatywa dla Niemiec.

Źródło: https://www.alternativefuer.de/, sty-

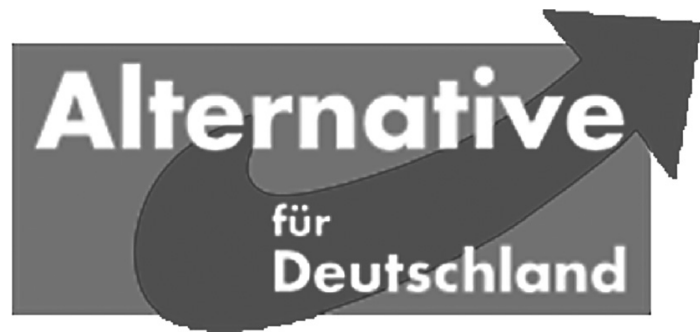
czeń 2014.

Logotyp partii prezentuje głównie nazwę, klasyczne, niebieskie tło, prostokątny kształt, białe litery, prosta przejrzysta czcionka. Na takim tle wyraźnie wybija się czerwona, wzrastająca strzałka, która na tak subtelnym tle jest dominującym elementem graficznym.

W wyborach do Bundestagu partia posługiwała się w zasadzie tylko jednym sloganem wyborczym, który brzmiał „Mut zur Wahrheit”, co można by przetłumaczyć jako „Odwaga do prawdy”. Na stronie w zakładce „Programm\&Hintergrund” pojawiło się uzasadnienie takiej presupozycji:

„Odwaga i prawda są teraz konieczne, ponieważ mamy do czynienia z:

1) kastą polityków, która systematycznie ukrywa przed narodem wszystkie problemy naszych czasów;

2) mediami, które zbliżyły się do polityków tak bardzo, że straciły wobec nich jakikolwiek krytyczny dystans;

3) strażnikami »politycznej poprawności«, którzy za pomocą tabuizacji całych dziedzin zamierzają zbudować bariery myślowe w naszych umysłach" (https://www.alternativefuer.de/programm-hintergrund/mut-zur-wahrheit/).

Trzeba nadmienić, że już z chwilą powstania AfD miała kłopoty wizerunkowe; mimo prezentowania się jako ,partia zdrowego rozsądku”, zbierała negatywne opinie na temat jej struktury i programu. Często podnoszonym zarzutem było sugerowanie, że jest to partia jednego aktora, bez wyraźnej ideologicznej przynależności. Na łamach „Die Zeit” Ca- 
terina Lobenstein napisała, że hasło, za które Lucke zbiera poklask: „Musimy mieć możliwość rozmawiania w sposób otwarty co do wyniku także o niekonwencjonalnych poglądach", jest niebezpieczne, ponieważ integruje wszystkich sfrustrowanych wyborców z różnych grup społecznych i politycznych. Ze sfrustrowanymi eurosceptykami Lucke „otwarcie” rozmawia o wykluczeniu Grecji ze Strefy Euro, ze zwolennikami Sarrazina ${ }^{15}$ „otwarcie” rozmawia o problemie imigrantów i o migracjach, zaś z krytykami państwa socjalnego „otwarcie” rozmawia o bezrobotnych; w ten sposób Lucke ściąga ludzi do AfD, samemu nie musząc określać się ideologicznie (Lobenstein, „Die Zeit"').

Fakt, że partia sama unika jednoznacznej afiliacji politycznej, powoduje, że czynią to za nią inni - np. dziennikarze. Taki zewnętrzny labelling doprowadził do tego, że partia już zyskała miano skrajnie prawicowej (brunatnej), mimo wielokrotnych deklaracji neutralności. Nie pomaga też to, że coraz częściej przytaczane są w mediach lub na portalach społecznościowych wypowiedzi członków AfD o konieczności przeciwdziałania „zalewowi Europy przez plemiona orientalne i negroidalne” oraz o ,niszczeniu kultur poprzez ich mieszanie” (Lobenstein, „Die Zeit”). Obecnie dziennikarze i komentatorzy życia politycznego, coraz częściej piszą o AfD jako o niemieckiej „Tea party”"16 (http://www.dw.de/ german-afd-tries-to-shake-off-tea-party-tag/a-17506323), co z całą pewnością uderza w wizerunek partii neutralnej ideologicznie, do którego aspiruje AfD.

Z inną dyskusją konstytuującą wizerunek musieli zmierzyć się członkowie i sympatycy AfD w kontekście motta i grafiki nawołującej do poparcia partii w wyborach do Parlamentu Europejskiego. Pierwotny slogan „Odwaga do prawdy” przekomponowany został „Mut zu D(EU)tschalnd”. „Odwaga na Niemcy”.

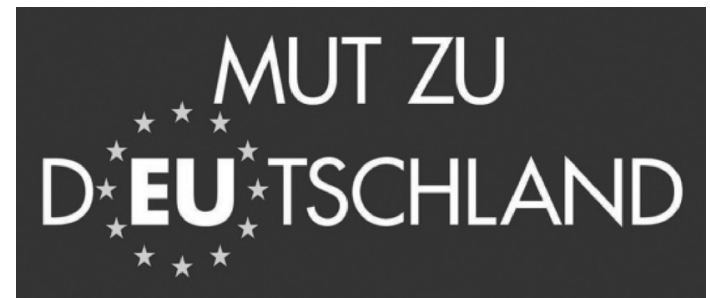

Źródło: https://www.alternativefuer.de/, styczeń 2014.

Heribert Prantl, redaktor naczelny „Süddeutsche Zeitung” w Monachium, w artykule Jasne zobowiqzania dla Europy, który ukazał się 27 stycznia na łamach SdZ, zasugerował, że ,motto wyborcze AfD to nawoływanie do renacjonalizacji, które powinno zmusić pozostałe partie do politycznych deklaracji, a nie bełkotu" (Prantl, sueddeutsche.de). I dalej „Motto AfD spycha Europę do przeszłości, do rozdrobnienia i małomiasteczko-

${ }^{15}$ Dr Thilo Sarrazin, niemiecki ekonomista, autor licznych publikacji, nie tylko na tematy gospodarcze, ale również społeczne. Autor książki Deutschland schafft sich ab: Wie wir unser Land aufs Spiel setzen (Niemcy likwiduja się same: Jak wystawiamy nasz kraj na ryzyko). Książka wywołała ogólnonarodową debatę o imigrantach, http://pl.wikipedia.org/wiki/Thilo_Sarrazin, styczeń 2014.

${ }^{16}$ Tea Party to skrajnie konserwatywne ugrupowanie (o charakterze oddolnego ruchu społecznego) amerykańskich Republikanów, które wyrosło na fali protestów w 2009 roku przeciwko reformom G. Busha (http://www.teaparty.org/). 
wości, do życia obok siebie i przeciwko sobie. To motto, które ma na celu nie wzmocnienie, lecz skurczenie; nie zreformowanie Unii Europejskiej od góry do dołu, lecz jej kastrację. Należy mieć nadzieję, że AfD zmusi w ten sposób inne partie do zajęcia jasnych pozycji” (Prantl, sueddeutsche.de).

Odpowiedzią na ten tekst była wypowiedź przewodniczącego Rady Naukowej AfD prof. Joachima Starbatty'ego, na spotkaniu w Tybindze 28 stycznia br. „AfD nie jest partią antyeuropejską. Nie da się tego też wyczytać z jej motta. Prantl pomija, że na plakacie litery EU są wytłuszczone i otoczone europejskimi gwiazdami. Przesłanie tego plakatu brzmi: «Odwaga na więcej Niemiec w Unii Europejskiej»” (https://www.alternativefuer.de/2014/01/28/sz-27-01-2014-europa-2014-schicksalswahl/).

$\mathrm{Na}$ stronie internetowej zarząd AfD zamieścił polemikę z mediami thumacząc, że media, zamiast przekazywać informacje o tym, co się faktycznie dzieje, szukały tylko sensacji, kłótni i skandali: „AfD odniosła za duży sukces, stała się niebezpieczna dla tradycyjnych struktur władzy. Stało się to, co zwykle dzieje się w Niemczech w takiej sytuacji: wyciągnięto „prawicową pałkę”. Niemal w ogóle nie pojawiały się artykuły o AfD, które nie zawierałyby w nagłówku pojęć: ,,prawicowi populiści”, ,prawa ręka” czy ,jak prawicowa jest AfD”. Z „Anty-Euro” zrobiono „Anty-Europę”, a z tego „przeciwników Europy". Kto jest przeciwko Europie, ten jest przeciw Niemcom, a kto jest przeciw Niemcom, to już w zasadzie jest nazistą? (http://www.alternativefuer.de/programm-hintergrund/mut-zur-wahrheit/die-afd-den-medien/).

Wyżej wymienione przykłady jasno wskazują na to, że pozostawienie zbyt szerokiego marginesu dowolności interpretacji tożsamości partii, prowadzi do wizerunkowego labbelingu.

\section{Potencjal medialny a potencjal wyborczy}

Partia, jak zostało wspomniane wyżej, powstała pół roku przed wyborami do Bundestagu. Wybór takiego terminu nie był przypadkowy. Jak wskazuje Tomasz Sikora, taki czas gwarantuje, że wyborcy zdążą się z partią i jej kontrowersyjnym programem oswoić, z drugiej strony do wyborów partia będzie wykorzystywała tzw. „efekt świeżości”, nie zdąży też nazbierać karnych punktów za nietrafione posunięcia/wypowiedzi (Sikora, http://niemcy-online.pl/komentarze/764-alternatywa-dla-niemiec.html). Czyli udało jej się do aktu wyborczego utrzymać to, czym zachwycili społeczeństwo niemieckie w 2012 r. - czyli „potencjałem świeżości” podobnym do Partii Piratów. Piratom w pewnym momencie (konkretnie do sierpnia 2012 r.) prognozowano spektakularne ,wejście” do parlamentu (Walecka-Rynduch, 2013, s. 177-197).

Jak się wskazuje w przypadku Alternatywy, istotny dla jej medialnego wizerunku jest nie tyle ostateczny wyborczy wynik, co prognozowana wzrostowa tendencja wyborcza, ponieważ wzmacnia ją w odbiorze opinii publicznej (Sikora, http://niemcy-online.pl/komentarze/764-alternatywa-dla-niemiec.html).

Aby pokazać taką tendencję, należałoby skorzystać $\mathrm{z}$ odpowiedniego narzędzia badawczego, opartego o metodologię pomiaru działań public relations w zakresie komunikowania $w$ internecie. Badając potencjał medialny partii pozaparlamentarnych powinno zwrócić się uwagę na trzy zasadnicze obszary: 


\section{EKSPOZYCJA $\rightarrow$ ODBIÓR $\rightarrow$ DZIALANIE ${ }^{17}$}

EKSPOZYCJA - oznacza wybór strategii politycznej, opartej na promocji wizerunkowej organizacji;

ODBIÓR - oznacza rozpoznawalność i zainteresowanie działaniami partii;

DZIAŁANIE - to analiza podjętych przez wyborców decyzji, analiza działań pozy-

tywnych - poparcia danej opcji politycznej, przy uwzględnieniu czynnika absencji wyborczej.

Na potrzeby artykułu, i ze względu na stosunkowo krótką jeszcze obecność partii na scenie politycznej, do analizy wykorzystam tyko ostatni element, czyli „działanie”, pokazując, jakie tendencje wykazywali niemieccy wyborcy i jak ostatecznie przełożyło się to na wyborczy wynik. Oprę się tu na danych publikowanych przez niemieckie ośrodki badania opinii publicznej.

\section{Ekspozycja marzec 2013 - powstanie partii}

Zgodnie $\mathrm{z}$ badaniami przeprowadzonymi w momencie powstania partii, instytut TNS Emnid prognozowal poparcie na poziomie 26\%, a Instytut Forsa na poziomie $23 \%$ (FDP-Politiker..., „Handelsblatt”). Widoczna tu jest tylko tendencja i chęć zagłosowania na nowa, wyrazistą partię. $\mathrm{W}$ badaniach przeprowadzanych w kwietniu, maju, czerwcu i lipcu realne poparcie bezpośrednio dla AfD szacowane było na poziomie 2-3\% (http://www.wahlrecht.de/umfragen/forsa.htm).

Natomiast w kwietniowej ocenie politologa Oskara Niedermayera, AfD mogłaby zagrozić kontynuacji czarno-żółtej koalicji (http://www.welt.de/politik/deutschland/article115062994/24-Prozent-liebaeugeln-mit-Wahl-der-Anti-Euro-Partei.html). Zgodnie z przywoływanymi przez niego badaniami, dysponowała ona sporym potencjałem wyborczym. Wprawdzie Niedermayer wattpił, aby AfD pokonała próg wyborczy, ale zwracał uwagę, że może ona przejąć głosy decydujące o losie FDP - co się faktycznie sprawdziło. Jednak jak pokazywało kwietniowe badanie Infratest Dimap przeprowadzone dla gazety „Welt am Sonntag”, w tym czasie, „24\% Niemców dopuszczało możliwość zagłosowania w wyborach do Bundestagu na ten nowy ruch. Na pytanie «Czy dopuszczasz w wyborach do Bundestagu zagłosowanie na eurokrytyczną partię, jaką jest AFD»", 7\% odpowiada „na pewno tak”, a 17\% „być może tak”, zaś 59\% badanych wyklucza możliwość zagłosowania na AfD. Badanie przeprowadzono 3-4.04.2013 r. na próbie 1000 osób.

Ankieta ta pokazuje większy potencjał dla tej partii w Niemczech Wschodnich (27\%) niż w Zachodnich (23\%) oraz większą popularność wśród kobiet (27\%) niż wśród mężczyzn (21\%). Osoby z wyższym wykształceniem częściej popierają AfD - 33\%, niż osoby ze średnim wykształceniem - 10\%, zaś wśród młodzieży w wieku 18-22 lat partia ma większe szanse $-36 \%$, niż wśród seniorów (powyżej 60 roku życia) - 18\%.

\footnotetext{
${ }^{17}$ Opracowanie własne. Opisana metoda jest wykorzystywana przeze mnie w szerszych badaniach wizerunkowych niemieckich partii pozaparlamentarnych.
} 


\section{Kömmen Sie sich vorstellen, bei der Bundestagagswahl eine Euro-kritische Partei wie} die AfD zu wählen?

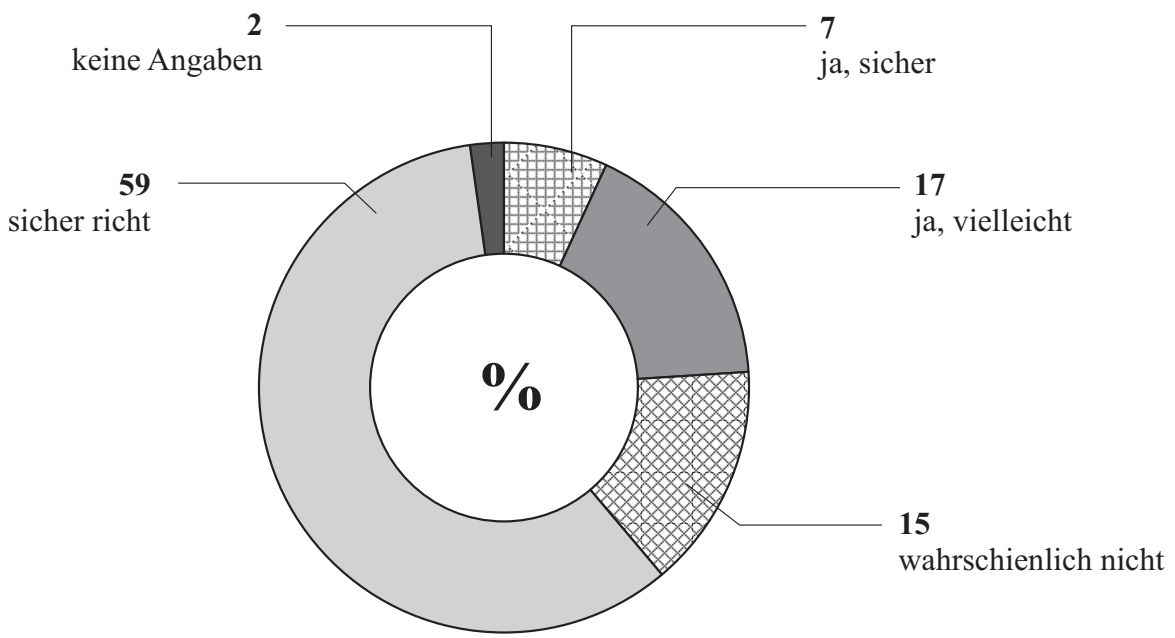

Quelle: Infratest dimap.

Źródlo: http://www.welt.de/politik/deutschland/article115062994/24-Prozent-liebaeugeln-mit-Wahl-derAnti-Euro-Partei.html, styczeń 2014.

W opinii Richarda Hilmera, Prezesa Instytutu Infratest, jeśli kryzys gospodarczy nadal będzie się tak rozwijał, to AfD może być pewna dużego zainteresowania. Decydującym dla wyniku wyborczego będzie to, „czy obywatele nadal ufają Pani Kanclerz Angeli Merkei i Ministrowi Finansów Wolfgangowi Schäuble, czy też zwątpią w którymś momencie w ich umiejętność zarządzania kryzysem” (Bewarder, Gaugele, „Die Welt").

W sierpniu 2013 r. ukazał się artykuł na łamach „Deutsche Wirtschaftsnachrichten”, w którym założyciel i szef Instytutu Forsa Manfred Güllner ostrzegał przed widocznym (nawet w badaniach jego Instytutu) niedoszacowaniem wyników Alternatywy. Dostrzegł istniejącą tendencję wzrostową poparcia dla partii i stwierdził, że jeśli z obecnych 2-3\% partia ta przekroczy granicę 4\%, to wejście do Bundestagu będzie w jej zasięgu. A niedoszacowanie wynika z nieszczerych odpowiedzi obywateli w badaniach opinii publicznej, którzy niechętnie przyznają się do ,alternatywnych” sympatii politycznych (Forsa-Chef widerspricht..., „Deutsche Wirtschaftsnachrichten”).

\section{Ekspozycja wrzesień 2013 - wybory do Bundestagu: „DZIALANIE”}

Wybory do Bundestagu miały miejsce 22 września 2013 r. Frekwencja wyniosła $71 \%$. Zaskoczeniem był wynik AfD, która uzyskała wynik: $4,7 \%$, bardzo mało zatem jej brakło, aby przekroczyć 5\% próg wyborczy. Wyniki wyborów ukształtowały się w następujący sposób: CDU/CSU uzyskało wynik 41\%, SPD - 25,7\%, Zieloni - 8,4\%, Lewica $-8,6 \%$. Poza Bundestagiem pozostała FDP (http://www.spiegel.de/international/germany/bild-924498-548046.html). 
Graf obrazujący wyniki wyborów w Niemczech oraz straty punktowe w stosunku do wyborów z 2009 r.:

Preliminary final results

\section{Results in Percent}

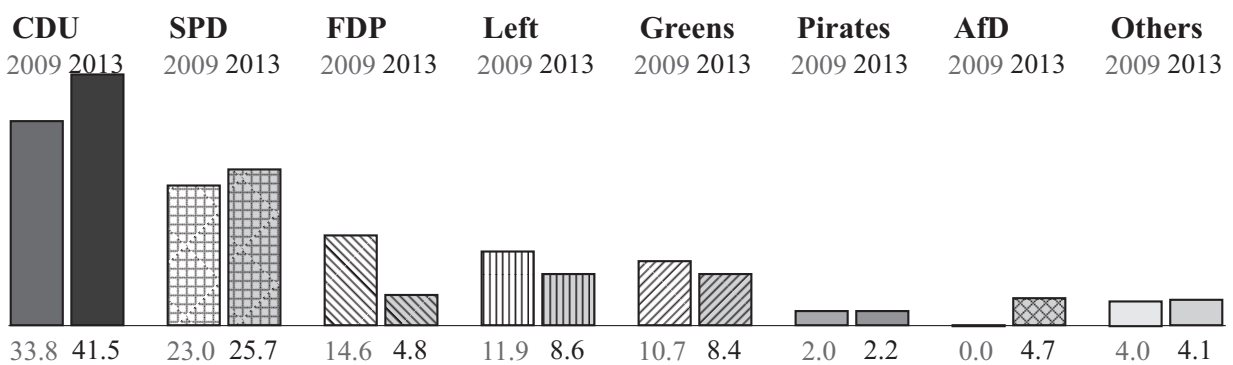

Gains and Losses

compared to 2009 election

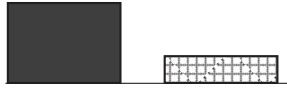

$+7.7$

$$
+2.7
$$
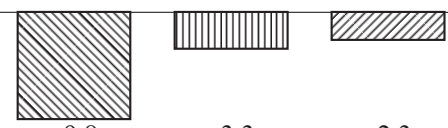

$-3.3$

$-2.3$

$+0.2$

$+4.7$

$+0.1$

Źródło: http://www.spiegel.de/international/germany/bild-924498-548046.html, maj 2014.

Kolejne badanie preferencji politycznych wyborców w Niemczech przeprowadzone przez Instytut Forsa w październiku 2013 r. pokazało, że w przypadku ponownych wyborów Alternatywie udałoby się wejść do Bundestagu z poparciem $6 \%$ - wyraźnie uwidacznia się tu prognozowana tendencja wzrostowa (Neue Umfrage..., „Die Welt”).

\section{Ekspozycja styczeń 2014 - przygotowanie do wyborów europejskich}

Instytut Forsa co tydzień (od 1949 roku) zadaje obywatelom Niemiec na zlecenie tygodnika „Stern” oraz stacji telewizyjnej RTL tzw. „Pytanie na niedzielę” (Sonntagsfrage), które zawsze brzmi „Na którą partię Pan/Pani by głosowała, gdyby wybory były w tę niedzielę?" (http:/de.statista.com/statistik/daten/studie/953/umfrage/aktuelle-parteipraeferenz-bei-bundestagswahl/).

Zgodnie z danymi na koniec stycznia, poparcie dla AfD sięgało 4\%. Inne niezależne instytuty badawcze pokazywały podobny lub nawet nieco większy wynik.

\begin{tabular}{|c|c|c|c|c|c|c|c|c|}
\hline Instytut & $\begin{array}{l}\text { Allens- } \\
\text { bach }\end{array}$ & Emnid & Forsa & $\begin{array}{c}\text { Forsch'gr. } \\
\text { Wahlen }\end{array}$ & GMS & $\begin{array}{c}\text { Infratest } \\
\text { dimap }\end{array}$ & INSA & $\begin{array}{l}\text { Wybory do } \\
\text { Bundestagu }\end{array}$ \\
\hline $\begin{array}{l}\text { Data } \\
\text { publikacji }\end{array}$ & $\begin{array}{c}29.01 . \\
2014\end{array}$ & $\begin{array}{c}26.01 . \\
2014\end{array}$ & $\begin{array}{c}29.01 . \\
2014\end{array}$ & $\begin{array}{c}17.01 . \\
2014\end{array}$ & $\begin{array}{c}21.01 . \\
2014\end{array}$ & $\begin{array}{c}09.01 . \\
2014\end{array}$ & $\begin{array}{c}27.01 . \\
2014\end{array}$ & $\begin{array}{c}22.09 \\
2013\end{array}$ \\
\hline 1 & 2 & 3 & 4 & 5 & 6 & 7 & 8 & 9 \\
\hline $\mathrm{CDU} / \mathrm{CSU}$ & $40,0 \%$ & $41,0 \%$ & $42,0 \%$ & $43,0 \%$ & $42,0 \%$ & $41,0 \%$ & $41,0 \%$ & $41,5 \%$ \\
\hline
\end{tabular}


PP 1 '15 „Alternative für Deutschland” - niemiecka eurosceptyczna partia...

\begin{tabular}{|l|r|r|r|r|r|r|r|r||}
\hline \multicolumn{1}{|c|}{1} & \multicolumn{1}{c|}{2} & \multicolumn{1}{c|}{3} & \multicolumn{1}{c|}{4} & \multicolumn{1}{c|}{5} & \multicolumn{1}{c|}{6} & \multicolumn{1}{c|}{7} & \multicolumn{1}{c|}{8} & \multicolumn{1}{c||}{} \\
\hline SPD & $26,0 \%$ & $26,0 \%$ & $23,0 \%$ & $24,0 \%$ & $25,0 \%$ & $27,0 \%$ & $26,5 \%$ & $25,7 \%$ \\
\hline GRÜNE & $10,0 \%$ & $9,0 \%$ & $11,0 \%$ & $9,0 \%$ & $9,0 \%$ & $9,0 \%$ & $9,5 \%$ & $8,4 \%$ \\
\hline FDP & $5,0 \%$ & $5,0 \%$ & $4,0 \%$ & $4,0 \%$ & $4,0 \%$ & $4,0 \%$ & $4,5 \%$ & $4,8 \%$ \\
\hline DIE LINKE & $8,5 \%$ & $9,0 \%$ & $9,0 \%$ & $10,0 \%$ & $9,0 \%$ & $8,0 \%$ & $8,5 \%$ & $8,6 \%$ \\
\hline AfD & $\mathbf{5 , 0 \%}$ & $\mathbf{4 , 0} \%$ & $\mathbf{4 , 0} \%$ & $\mathbf{4 , 0} \%$ & $\mathbf{4 , 0} \%$ & $\mathbf{4 , 0} \%$ & $\mathbf{4 , 0 \%}$ & $\mathbf{4 , 7 \%}$ \\
\hline Inne & $5,5 \%$ & $6,0 \%$ & $7,0 \%$ & $6,0 \%$ & $7,0 \%$ & $7,0 \%$ & $6,0 \%$ & $6,2 \%$ \\
\hline
\end{tabular}

Źródlo: Sonntagsfrage Bundestagswahl, http://www.wahlrecht.de/umfragen/index.htm, styczeń 2014.

W kontekście wyborów europejskich, zgodnie z prognozą Emnid na dzień 26.01.2014 r., Alternatywa mogłaby uzyskać $7 \%$ poparcie (http://www.spiegel.de/politik/deutschland/emnid-umfrage-afd-kaeme-bei-europawahl-aufsieben-prozent-a-945586.html). AfD wykorzystywała takie statystyki w plakatach i w grafice prezentowanej na stronie internetowej.

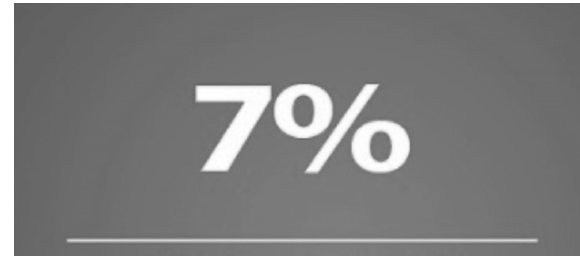

AfD derzeit bei $7 \%$

Emnid Umfrage vom 26. Januar 2014

\section{Alternative}

Deutschland

Źródło: https://www.alternativefuer.de/, styczeń 2014.

\section{Ekspozycja maj 2014 - wybory do Parlamentu Europejskiego: „DZIALANIE"}

I faktycznie takie wyliczenie potwierdziło się. AfD zdobyła 7\% poparcia społecznego, pokonując wielką przegraną jesiennych wyborów do Bundestagu - FDP. Trzeba zaznaczyć, że frekwencja wyborcza w Niemczech w wyborach to Parlamentu Europejskiego wyniosła 48,1\% i była czwartą niższą w całej historii niemieckich wyborów europejskich. Odnotować należy, że wzrost z 43,27\% z roku 2009 do 48,1\% w 2014 r. może świadczyć o pojawiającej się tendencji zwyżkowej uczestnictwa obywateli w procesie wyborczym $^{18}$.

Schemat poparcia dla niemieckich partii politycznych, startujących w wyborach do Parlamentu Europejskiego:

${ }^{18}$ Dane dotyczące frekwencji wyborczej w wyborach do Parlamentu Europejskiego w Niemczech: 1979 r. $-65,7 \%$; 1984 r. $-56,8 \%$; 1989 r. $-62,3 \% ; 1994$ r. $-60 \%$; 1999 r. $-45,2 \%$; 2004 r. $-43 \%$; 2009 r. - 43,3\%; 2014 r. - 48,1\%, za: Wahlbeteiligung bei den Europawahlen in Deutschland bis 2014,

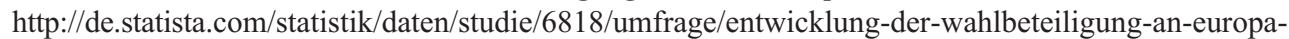
wahlen-seit-1979/, maj 2014. 


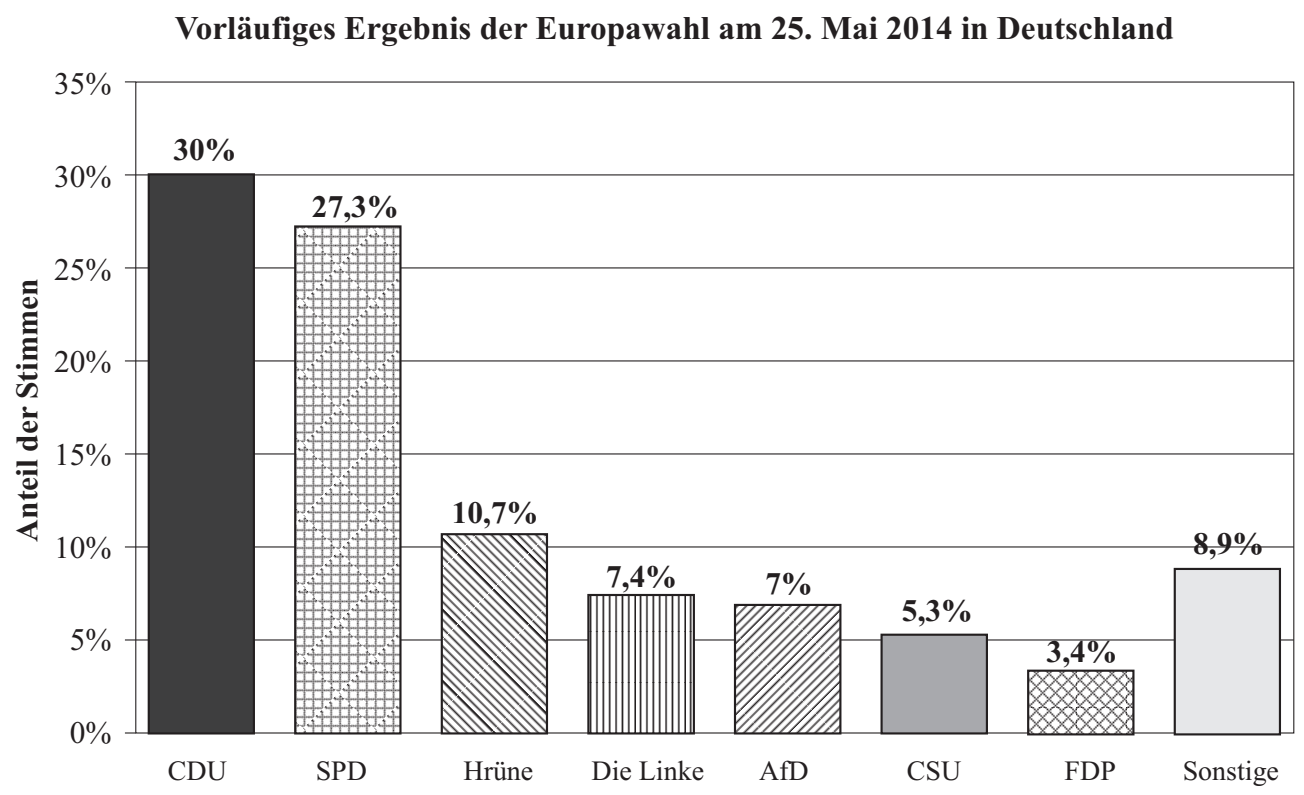

Źródło: http://de.statista.com/statistik/daten/studie/12327/umfrage/amtliches-ergebnis-der-europawahl-2009/, maj 2014.

Po zdobyciu 7\% poparcia na stronie www Alternatywy, pojawiła się od razu odpowiednia grafika z napisem „Bardzo dziękujemy”.

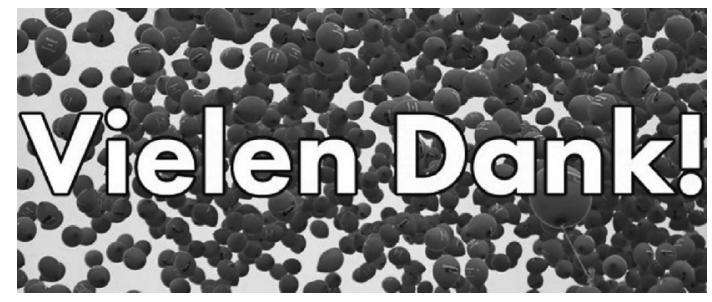

Źródło: https://www.alternativefuer.de/7-fuer-die-afd/, maj 2014.

oraz bardziej żartobliwa w wyrazie „Brukselo, nadchodzimy”:

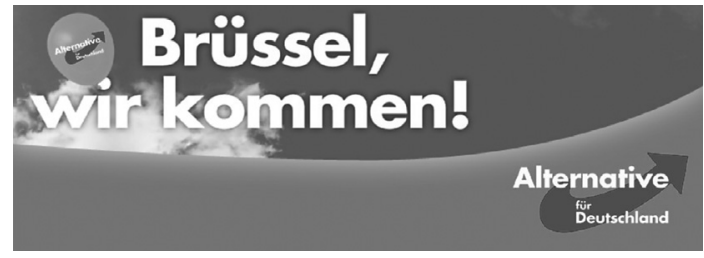

Źródło: https://www.alternativefuer.de/.

Przedstawiono również siedmiu polityków, którzy wywalczyli mandaty eurodeputowanych $^{19}$ :

${ }^{19}$ Są nimi w kolejności od lewej: Marcus Pretzell, Bernd Kölmel (Baden-Württemberg), Beatrix von Storch (Berlin), Bernd Lucke (Niedersachsen), Ulrike Trebesius (Schleswig-Holstein), Hans-Olaf Henkel (Berlin), Joachim Starbatty (Baden-Württemberg). 


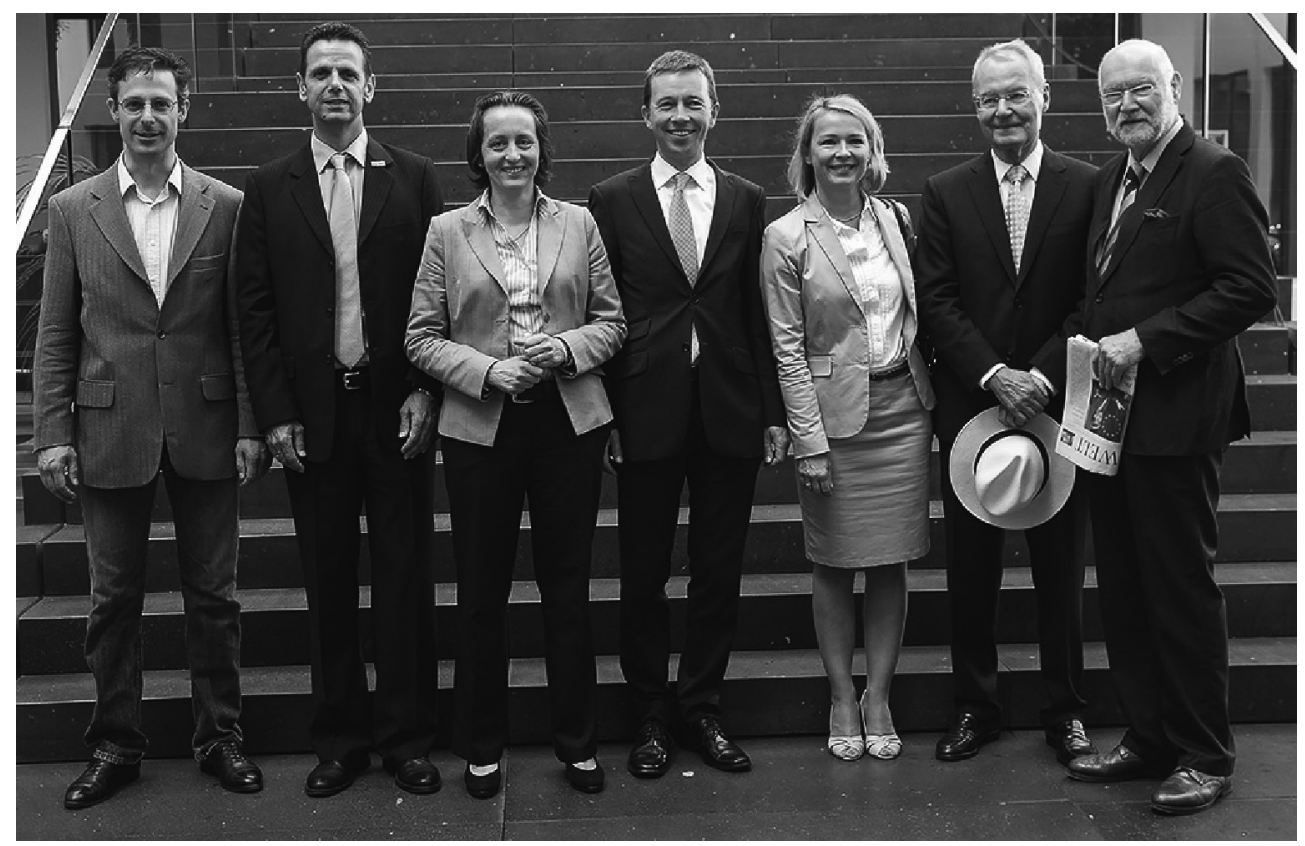

Źródło: https://www.alternativefuer.de/.

\section{Zakończenie}

Czas pokaże, jak potoczą się losy partii. Może czekać ją podobny los jak „Piratów”, czyli po pierwszym „zachłyśnięciu się” innością wyborcy powrócą do utartych dróg wyborów politycznych. W sierpniu 2012 roku A. Meritz na łamach „Der Spiegel” wskazała na pięć przyczyn, które są podstawą upadku, źle prowadzonej polityki partii. Autorka wprawdzie mówiła o „Niemieckiej Partii Piratów”, ale myślę, że te problemy dotyczą wszystkich partii pozaparlamentarnych, które w jakimś momencie otrzymują mandat społecznego zaufania. Meritz zaliczyła do nich: generowanie kontrowersji zamiast debaty, wzrastająca ilość „wpadek”, brak wizji i strategii, roszczeniowa postawa i w końcu „koniec powiewu świeżości” (Meritz, www.spiegel.de).

Alternatywa musi się również zmierzyć z problemem przypisania jej, mimo programowej neutralności i założenia, że będzie partią ,nowego typu”, do konkretnej grupy ideologicznej - skrajnej prawicy. Oczywiście nie można zakładać, że nawet gdyby tak było, uda jej się pod swoim szyldem zjednoczyć wszystkie radykalne, ale i podzielone politycznie i programowo ugrupowania.

Z całą pewnością zdobycie mandatów do Parlamentu Europejskiego otwiera dla Alternatywy co najmniej pięcioletni okres „,rzeczywistego" funkcjonowania na scenie politycznej, który umożliwi głębszą ocenę relacji pomiędzy wagą polityczną a wizerunkiem medialnym tej partii. Na dzień dzisiejszy można ocenić, że budowanie wizerunku głównie w oparciu o przestrzeń internetu pomogło, o ile nie zaważyło na osiągnięciu medialnego rozgłosu, a za nim realnego poparcia. 


\section{Bibliografia}

Black S. (2005), Public Relations, Kraków.

della Porta D., Diani M. (2009), Ruchy społeczne. Wprowadzenie, Kraków.

Dobek-Ostrowska B. (2007), Komunikowanie polityczne i publiczne, Warszawa.

Fras J. (2010), Samoidentyfikacja polskich partii politycznych, w: Polska scena, polityczna. Środowiska - komunikacja polityczna - strategie, red. K. Sobolewska-Myślik, A. Hess, K. Kowalczyk, Kraków.

Hess A. (2013), Społeczni uczestnicy medialnego dyskursu politycznego w Polsce. Mediatyzacja i strategie komunikacyjne organizacji pozarzqdowych, Kraków.

Kaczmarek-Śliwińska M. (2010), Internet public relations. Polskie realia działań public relations $w$ sieci, Koszalin.

McGraw K. M. (2008), Wizerunki polityczne: tworzenie i sterowanie, w: Psychologia polityczna, red. D. O. Sears, L. Huddy, R. Jervis, Kraków.

Marciniak E. M. (2012), Relacyjna teoria komunikacji a marketing relacyjny w polityce, „Studia Politologiczne", vol. 24.

Michalczyk S. (2009), Pojęcie mediatyzacji w nauce o komunikowaniu, w: Mediatyzacja kampanii politycznych, red. M. Kolczyńskiego, M. Mazura, S. Michalczyka, Katowice.

Paleczny T. (2011), Nowe ruchy społeczne $w$ warunkach globalizacji, w: Wspótczesna przestrzeń polityczna. Ewolucja czy rewolucja?, red. M. du Vall, M. Majorek, A. Walecka-Rynduch, Kraków.

Piontek D. (2009), Mediatyzacja polityki w tzw. mediach miękkich wiadomości. Polityczni celebryci jako nowy element komunikowania politycznego, w: Mediatyzacja kampanii politycznych, red. M. Kolczyńskiego, M. Mazura, S. Michalczyka, Katowice.

Podobas I. (2011), Public relations jako narzędzie kreowania wizerunku partii politycznych, Warszawa.

Rozwadowska B. (2009), Public Relations. Teoria i praktyka, Warszawa.

Rychter K., Chmielewski Z., Tworzydło D. (red.) (2012), Tożsamość wizualna. Znak, system, wizerunek, Rzeszów.

Seitel F. S. (2003), Public relations w praktyce, Warszawa.

Walecka-Rynduch A. (2013), Niemiecka Partia Piratów, czyli praktyka wirtualnej demokracji, w: Demokracja elektroniczna kontrowersje i dylematy, red. M. Marczewska-Rytko, Lublin.

Walecka-Rynduch A. (2013), Some aspects of political public relations strategy based on the example of polish extra-parliamentary left-wing parties. the first decade of the $21^{\text {st }}$ century, „Przegląd Politologiczny", nr 3.

Wojcik K. (2005), Public relations. Wiarygodny dialog z otoczeniem. Podręcznik dla teoretyków. Poradnik dla praktyków, Warszawa.

\section{Netografia:}

\section{Materiały opublikowane na stronie partii Alternative fuer Deutschland:}

https://www.alternativefuer.de/partei/wahlprogramm/, styczeń 2014.

https://www.alternativefuer.de/partei/wahlprogramm/, styczeń 2014.

https://www.alternativefuer.de/partei/unterstutzer/, styczeń 2014.

http://www.zeit.de/2013/51/afd-alternative-fuer-deutschland-rechts, dane na grudzień 2013 r., styczeń 2014.

https://www.alternativefuer.de/2014/01/28/sz-27-01-2014-europa-2014-schicksalswahl/, styczeń 2014. 
https://www.alternativefuer.de/grosse-aufmerksamkeit-fuer-afd-antwortet, maj 2014.

https://www.alternativefuer.de/programm-hintergrund/mut-zur-wahrheit/, maj 2014.

http://www.alternativefuer.de/programm-hintergrund/mut-zur-wahrheit/die-afd-den-medien/, maj 2014.

https://www.alternativefuer.de/wp-content/uploads/2014/05/AfD_Kompakt_06_14.pdf, maj 2014.

\section{Artykuły prasowe:}

FDP-Politiker wechselt zur Anti-Euro-Partei, „Handelsblatt”, 17.03.2013, www.handelsblatt.com/ politik/deutschland/alternative-fuer-deutschland-fdp-politiker-wechselt-zur-anti-euro-partei/7941300.html, styczeń 2014.

Forsa-Chef widerspricht eigenen Umfragen: AfD hat Chance auf den Bundestag, „Deutsche Wirtschaftsnachrichten", 16.08.2013, http://deutsche-wirtschafts-nachrichten.de/2013/08/16/forsa-chef-widerspricht-eigenen-umfragen-afd-hat-chance-auf-den-bundestag/, styczeń 2014.

Małkiewicz A., Kessler R., Miejsce i perspektywy rozwoju pozaparlamentarnej partii politycznej na polskiej scenie politycznej na przykładzie Partii Demokratycznej - demokraci.pl, http://www.demokraci.pl/slownik/images/stories/analiza.pdf, styczeń 2014.

Meiritz A., Plötzlich uncool, 22.08.2012, http://www.spiegel.de/politik/deutschland/umfragen-im-sinkflug-fuenf-gruende-warum-die-piraten-abstuerzen-a-851456.html, 30 sierpnia 2012.

Neue Umfrage sieht AfD bei sechs Prozent, „Die Welt”, 9.10.2013, http://www.welt.de/politik/ deutschland/article120751085/Neue-Umfrage-sieht-AfD-bei-sechs-Prozent.html, styczeń 2014.

Prantl H., Klares Bekenntnis zu Europa, 27.01.2014, http://www.sueddeutsche.de/politik/wahl-deseu-parlaments-klares-bekenntnis-zu-europa-1.1872598, styczeń 2014.

Plickert P., Mehr als Euro-Kritik, „Frankfurter Allgemeine Zeitung”, 15. April 2013, http://www.faz.net/aktuell/wirtschaft/wirtschaftspolitik/alternative-fuer-deutschland-mehr-als-euro-kritik-12149612-p2.html, styczeń 2014.

Sikora T., Alternatywa dla Niemiec, 23.04.2013, http://niemcy-online.pl/komentarze/764-alternatywa-dla-niemiec.html, styczeń 2014.

Wie autoritär ist die AfD?, von Caterina Lobenstein, „Die Zeit”, 14 grudnia 2013, http://www.zeit.de/ 2013/51/afd-alternative-fuer-deutschland-rechts, styczeń 2014.

24 Prozent liebäugeln mit Wahl der Anti-Euro-Partei, von Manuel Bewarder und Jochen Gaugele, „Die Welt”, 6.04.2013, http://www.welt.de/politik/deutschland/article115062994/24-Prozent-liebaeugeln-mit-Wahl-der-Anti-Euro-Partei.html, styczeń 2014.

http://pl.wikipedia.org/wiki/Thilo_Sarrazin, styczeń 2014.

http://www.wahlrecht.de/umfragen/forsa.htm, styczeń 2014.

http://de.statista.com/statistik/daten/studie/953/umfrage/aktuelle-parteipraeferenz-bei-bundestagswa hl/, styczeń 2014.

http://www.spiegel.de/politik/deutschland/emnid-umfrage-afd-kaeme-bei-europawahl-auf-sieben-prozent-a-945586.html, styczeń 2014.

http://www.dw.de/niemiecka-tea-party-cichy-zwyci\%C4\%99zca-wybor\%C3\%B3w-do-bundestagu/ a-17104630, styczeń 2014.

http://www.dw.de/german-afd-tries-to-shake-off-tea-party-tag/a-17506323, maj 2014.

http://www.spiegel.de/international/germany/bild-924498-548046.html, maj 2014.

http://www.pi-news.net/wp/uploads/2014/05/eu-wahl_hr00.05.jpg, maj 2014.

http://de.statista.com/statistik/daten/studie/6818/umfrage/entwicklung-der-wahlbeteiligung-an-euro pawahlen-seit-1979/, maj 2014.

http://de.statista.com/statistik/daten/studie/12327/umfrage/amtliches-ergebnis-der-europawahl-2009/. 


\section{„Alternative für Deutschland” - the German Eurosceptic Extraparliamentary Party \\ Summary}

The Alternative for Germany is a new party on the German political scene. Despite a short political and media history (established in February 2013), the party managed to strongly mark the socio-political space with its presence, mostly because of its anti-establishmentarianism. AfD is also sometimes called a ,professors' party”, as its members and followers stem to a large extent from so-called intellectual circles of science, politics and economics, and are reputable experts for many fields. AfD provoked a major imbroglio during the last parliamentary election in Germany (2013). It gathered $4.7 \%$ of votes, standing very close to the electoral threshold. It is however commonly disregarded by activists of most of the other parties in Germany. The aim of the article is answering the question: given the above, what was the crucial factor for building up such relatively high electoral result (inches from bestowing mandates) in this very short time? Is it the social, programmatical, or rather media potential, created mostly on the web? Which of these elements brought the AfD 7\% of votes in the election for European Parliament 2014 ?

Key words: public relations, media potential, image identity, extraparliamentary parties, Alternative for Germany 